\title{
ОПТИМИЗАЦИЯ МИКРОКЛИМАТА ПТИЧНИКОВ В УСЛОВИЯХ КРАЙНЕГО СЕВЕРА
}

\author{
M.S. Savvinova, V.V. Matarkina
}

\section{THE OPTIMIZATION OF THE MICROCLIMATE OF POULTRY HOUSES IN THE CONDITIONS OF FAR NORTH}

Саввинова М.C. - д-р ветеринар. наук, проф. каф. ветеринарно-санитарной экспертизы и гигиены Якутской государственной сельскохозяйственной академии, г. Якутск.

E-mail: aantoeva@mail.ru

Матаркина В.В. - асп. каф. ветеринарносанитарной экспертизы и гигиены Якутской государственной сельскохозяйственной академии, г. Якутск.

E-mail: aantoeva@mail.ru

Цель исследования - разработка мероприятий по оптимизации параметров микроклимата птичников в экстремальных условиях Крайнего Севера. Исследование проводили в условиях Якутской птицефрабрики, в птичниках павильонного типа, на птицах, содержащихся 8 клеточных батареях, в условиях работы приточно-вытяжной вентиляции. Опытную и контрольную группу птиц выбирали по принципу аналогов. Опыты проведены на курах-несушках породы Hy-Line в возрасте 7, 12 месяиев, в опытной и контрольной группах - по 10 голов. Опьтная групnа птии содержится при нововведенной энергосберегающей системе вентиляции для оптимизации параметров микроклимата, а контрольная группа птиц - при традиционной вентиляционной системе. Зоогигиенические исследования проводились с использованием современных приборов мониторинга микроклимата. Определяли: температурно-влажностный режим; концентрацию вредных газов; относительную влажность воздуха; бактериальную обсемененность воздуха; содержание пыли. Для промера показаний микроклимата использованы приборы «Метеометр M-17» и ТК-3 БКМ - модель 41, газоанализатор универсальный УГ-2. В результаmе исследования были сделаны следующие
Savvinova M.S. - Dr. veterinary Sci., Prof., Chair of Veterinary and Sanitary Examination and Hygiene, Yakut State Agricultural Academy, Yakutsk. E-mail: aantoeva@mail.ru

Matarkina V.V. - Post-Graduate Student, Chair of Veterinary and Sanitary Examination and Hygiene, Yakut State Agricultural Academy, Yakutsk.

E-mail: aantoeva@mail.ru

выводы. При понижении температуры наружного воздуха до минус $45^{\circ} \mathrm{C}$ и ниже температурно-влажностный режим не отвечал ветеринарно-гигиеническим требованиям: температура была ниже, а влажность выше, влажный холодный воздух отрицательно действовал на организм птиц. Однако после реконструкции вентиляционно-отопительной системы в птичниках, когда подавался тепльй подогретьй воздух по периметру помещения, относительная влажность снизилась, воздух стал суше и температура в помещении повысилась, что послужило оптимизации параметров микроклимата. Установлено, что при поддержании оптимального температурновлажностного и светового режима резких колебаний фризиологических показателей у курнесушек не возникает. В условиях Якутии при температуре наружного воздуха минус $50^{\circ} \mathrm{C} u$ ниже немаловажное значение имеет организация утеплительных работ для ограждающих конструкций, эффрективная отопительная и вентиляционная система.

Ключевые слова: микроклимат, температура, влажность, вентиляция, санитарнозащитная зона (СЗ3), бактериальная обсемененность, птицефрабрика, Крайний Север. 
The aim of the research was to develop measures to optimize the parameters of the microclimate of poultry houses in extreme conditions of the Far North. The research was conducted in the conditions of the Yakut poultry farm, in poultry houses of stage type, on the birds kept in cage batteries, in operating conditions of the supply and exhaust ventilation. Experimental and control group of birds were chosen by the principle of analogs. The experiments were made on laying hens of breed of Hy-Line at the age of 7, 12 months, in experimental and control groups - up to 10 heads. Experimental group of birds was kept at newly introduced energy saving system of ventilation for optimization of parameters of microclimate, and control group of birds - at traditional ventilating system. Zoohygienic researches were conducted with using modern devices of microclimate monitoring. Temperature moisture conditions, the concentration of harmful gases, relative humidity of air; bacterial contamination of air, the content of dust were defined. For the measurement of indications of microclimate the devices "Meteometer M-17" and TK-3 PCM-model 41, universal gas analyzer UG-2 were used. As a result of the research the following conclusions were drawn. At the decrease of the temperature of external air to $-45^{\circ} \mathrm{C}$ and below temperature moisture conditions did not meet veterinary hygienic requirements: the temperature was lower, and the humidity was higher, damp cold air negatively affected birds' organisms. However, after the reconstruction of ventilating and heating system in poultry houses when warm and warmed-up air moved on room perimeter, relative humidity decreased, the air became dryer and the temperature indoors increased that served as optimization of microclimate parameters. It was established that at the maintenance of the optimum temperature and moist and light mode of sharp fluctuations of physiological indicators at laying hens did not arise. In the conditions of Yakutia at the temperature of external air of $-50{ }^{\circ} \mathrm{C}$ and below the organization of insulating works for protecting designs, effective heating and ventilating system had important value.

Keywords: microclimate, temperature, humidity regime, ventilation, sanitary and protection zone (SPZ), bacterial contamination, poultry farm, Far North.

Введение. Промышленное птицеводство как самая наукоемкая и динамичная отрасль агропромышленного комплекса вносит весомый вклад в обеспечение населения развитых стран продовольствием [2, 4].

Практика деятельности птицеводческих предприятий на Крайнем Севере свидетельствует о необходимости оптимизации параметров микроклимата при помощи эфффективных систем обеспечения микроклимата [1, 3].

Изыскание научно обоснованных оптимальных норм в условиях Крайнего Севера для условий обитания сельскохозяйственных животных и птиц с целью повышения неспецифической устойчивости организма всегда было крайне актуальной задачей в разработке системы мероприятий по обеспечению ветеринарного благополучия и получения высококачественной продукции [3].

В природно-климатической зоне Крайнего Севера вопрос оптимизации параметров микроклимата остается всегда актуальным.

Цель исследования: разработать мероприятия по оптимизации параметров микроклимата птичников в экстремальных условиях Крайнего Севера.

Для достижения поставленной цели были поставлены следующие задачи:

- изучить условия содержания кур-несушек в условиях Якутии;

- провести ветеринарно-гигиенические исследования микроклимата птичников в разные периоды года;

- определить влияние микроклимата на естественную резистентность, продуктивность и сохранность птиц;

- разработать меры оптимизации микроклимата птичников в условиях Якутии.

Условия, материалы и методы исследования. Работу выполняли в условиях ОАО «Якутская птицефабрика», на базе клиникодиагностической лаборатории ФГБОУ ВО Якутская ГСХА, а также на базе кафедры ветеринарно-санитарной экспертизы факультета ветеринарной медицины с использованием общепринятых методов исследований. Определяли: температурно-влажностный режим, концентрацию вредных газов, относительную влажность воздуха; бактериальную обсемененность воздуха (БОВ); содержание пыли по общепринятым методам. Методы исследования: для промера показаний микроклимата использованы приборы «Метеометр М-17» и ТК-3 БКМ - модель 41, 
газоанализатор универсальный УГ-2. Опытную и контрольную группу птиц выбирали по принципу аналогов. Опыты проведены на курахнесушках породы Hy-Line в возрасте 7, 12 месяцев, были созданы опытная и контрольная группы, в каждой по 10 голов. Опытная группа птиц содержится в условиях нововведенной энергосберегающей системы вентиляции для оптимизации параметров микроклимата, а контрольная группа птиц - в условиях работы традиционной вентиляционной системы.

Результаты исследования и их обсуждение. В результате ветеринарно-гигиенической оценки микроклимата в птичниках птицефабрики г. Якутска для улучшения его параметров нами были рекомендованы следующие мероприятия, которые внедрены в производство:

- реконструкция одноэтажных птичников с напольным содержанием птицы в клеточное многоярусное помещение для облегчения обслуживания и регулирования параметров микроклимата, повышения сохранности и продуктивности птицы;

- реконструкция вентиляционно-отопительной системы в птичниках с использованием электрокалориферов типа СФО для обогрева воздуха и улучшения микроклимата в связи с частой поломкой водяной системы вследствие замерзания воды в теплоносителе при температуре наружного воздуха минус $30^{\circ} \mathrm{C}$ и ниже.

Проект одноэтажного птичника после реконструкции по нашим предложениям представляет собой удлиненное безоконное здание. Фундамент свайный, железобетонный, с сохранением вечномерзлых грунтов путем устройства проветриваемого подполья. Стены из крупных стеновых керамзито-бетонных блоков, внутренние стены и перегородки кирпичные, полы в помещении основного назначения цементные, в остальном - цементно-бетонные. Покрытие совмещенное, рулонная кровля сборными железобетонными плитами.

Каждый производственный зал оборудован приточно-вытяжной вентиляцией с механическим побуждением воздуха. Приточная вентиляция ЦМ-6 подает воздух через калориферы КФС-8. Воздуховоды приточной вентиляции расположены по верхней части зала и идут по всей длине зала. Удаление отработанного воздуха из зала предусмотрено при помощи венти- ляторов ВО-7, расположенных в нижней части продольных и торцовых стен здания.

Яйценоскость кур после реконструкции вентиляционно-отопительной системы повысилась от 208 до 250 шт. в год от одной курицы. Внедрение новой технологии производства, применение безоконного содержания с регулируемым световым режимом и в связи с этим резкое улучшение микроклимата в птичниках позволило увеличить производство яиц в целом по птицесрабрике до 48 млн шт. в год.

Применение клеточного содержания без расширения производственных площадей улучшило условия труда работников и содержания птицы, увеличило мощность предприятия, сократило количество обслуживающего персонала и расходы на отопление помещений, снизило затраты труда и кормов на единицу продукции. Производительность труда повысилась в 2,5 раза, прибыль птицефабрики возросла. Благодаря клеточному содержанию птицы сохранность взрослого поголовья повысилась с 95,6 до 98,8 \%, а молодняка - с 90 до $96 \%$.

При переходе на клеточное содержание переоборудование систем для создания оптимального микроклимата вызвало большое опасение у специалистов птицефабрики. Несмотря на жестокие морозы, для удаления вредных веществ и излишней влаги за один час нужно обновить воздух помещения в полтора раза. Это значит, что если общая площадь птичника составляет 5 тыс. м², то за час из него необходимо удалить и, соответственно, подать взамен 7,5 тыс. м ${ }^{3}$ наружного воздуха. В зимний период надо его еще подогреть от минус $40-45{ }^{\circ} \mathrm{C}$ до плюс $16-18^{\circ} \mathrm{C}$. При реконструкции каждого цеха по нашим предложениям менялась вентиляция и вся система обеспечения микроклимата.

Температура внутри птичников поддерживается регулированием мощности электрокалорифера. Снижение относительной влажности воздуха производилось регулированием воздухообмена, осуществляемого изменением скорости вращения электродвигателей приточных и вытяжных вентиляторов и использованием перфорированного воздуховода в клетках. В результате проведенных нами исследований установлено, что температура воздуха внутри клеток была выше, чем в зале, на 3-4 \% (табл. 1). 
Температурно-влажностный режим в птичниках с содержанием кур-несушек после реконструкции отопительно-вентиляционной системы

\begin{tabular}{|c|c|c|c|c|c|c|c|c|}
\hline \multirow{2}{*}{$\begin{array}{c}\text { Возраст } \\
\text { птицы }\end{array}$} & \multicolumn{2}{|c|}{ Внутри клетки } & \multicolumn{2}{c|}{ В зале } & \multicolumn{2}{c|}{ В нижнем ярусе } & \multicolumn{2}{c|}{ В верхнем ярусе } \\
\cline { 2 - 9 } & $\mathrm{t},{ }^{\circ} \mathrm{C}$ & $\mathrm{R}, \%$ & $\mathrm{t},{ }^{\circ} \mathrm{C}$ & $\mathrm{R}, \%$ & $\mathrm{t},{ }^{\circ} \mathrm{C}$ & $\mathrm{R}, \%$ & $\mathrm{t},{ }^{\circ} \mathrm{C}$ & $\mathrm{R}, \%$ \\
\hline 7 месяцев & $17 \pm 0,4$ & $68 \pm 1,08$ & $16 \pm 0,24$ & $68,5 \pm 1,2$ & $19 \pm 0,36$ & $66 \pm 1,12$ & $16 \pm 0,28$ & $70 \pm 0,8$ \\
\hline 12 месяцев & $22 \pm 0,3$ & $69,5 \pm 0,8$ & $21 \pm 0,16$ & $70 \pm 0,9$ & $23 \pm 0,24$ & $68 \pm 2,08$ & $21 \pm 0,18$ & $71,5 \pm 1,1$ \\
\hline 14 месяцев & $23 \pm 0,16$ & $70 \pm 0,6$ & $22 \pm 0,12$ & $69 \pm 1,4$ & $24 \pm 0,18$ & $68 \pm 2,1$ & $21 \pm 1,3$ & $71 \pm 1,2$ \\
\hline
\end{tabular}

Из таблицы 1 видно, что температура была выше внутри клетки, чем в зале, по проходу, где больше аэрации при содержании птиц в возрасте 14 мес., что обусловлено биологической усталостью производственного зала.

Схема системы вентиляции, рекомендованная нами для Якутской ПТФ, состоит в следующем: подача воздуха должна осуществляться в холодное время через электрический калорифер (по нашему предложению заменили водяную систему на электрическую) по четырем воздуховодам, идущим по опорным балкам от торцов здания к центру. В переходный период открываются заслонки всех приточных вентиляционных шахт, расположенных в потолочном перекрытии. В теплое время года подача воздуха - через шахты в потолочном перекрытии естественным путем. Удаление воздуха во все периоды года из нижней зоны - при помощи осевых вентиляторов, вмонтированных в стеновые отверстия.

Большую концентрацию гемоглобина в крови несушек породы Hy-Line можно объяснить повышенными адаптационными процессами и естественной резистентностью организма в экстремальных условиях, меньшей стрессовой нагрузкой вследствие меньших габаритов производственного зала и плотности птицы.

В переходный период года стабилизируется воздействие вечной мерзлоты на объекты окружающей среды. При этом в условиях температуры наружного воздуха минус $30^{\circ} \mathrm{C}$ температура в производственных залах птичников становится в пределах оптимальной нормы, хотя, как нами отмечено, относительная влажность в одноэтажных птичниках оказывалась выше нормы на $7,6 \pm 1,8 \%$. Это вызвано разницей в режиме работы вентиляционно-отопительной системы (автономной - в одноэтажных). При указанных условиях микроклимата этого периода в птичниках у кур-несушек наблюдалось на-

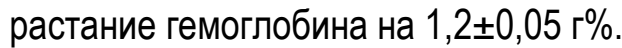

В связи с указанными изменениями активизируются все виды обмена веществ и возрастает устойчивость организма к неблагоприятным факторам внешней среды.

Так, температура окружающего воздуха оказывает существенное влияние на здоровье, жизнеспособность и продуктивность птицы. Например, максимальная яйценоскость (80 \%) и масса яиц отмечались у кур при температуре $13^{\circ} \mathrm{C}$. Продуктивность кур-несушек при снижении температуры воздуха в птичниках с плюс 12 до плюс $5{ }^{\circ} \mathrm{C}$ уменьшалась на $12 \%$, а при повышении температуры до плюс $30^{\circ} \mathrm{C}$ - падает на 28-30 \%. При резком снижении или повышении температуры в этих помещениях установили уменьшение яйценоскости до $50 \%$, на восстановление которой требовалось не менее десяти дней.

Однако с увеличением посадки тепловыделение у кур увеличивается. Кроме того, птица в состоянии беспокойства выделяет тепла на 30$40 \%$ больше, чем в состоянии покоя. То есть высокая концентрация ее поголовья привела к существенному изменению тепловых и фризиологических процессов в организме птицы и теплового баланса в птичниках.

На основании проведенных нами исследований можно сделать заключение, что в условиях Крайнего Севера развитие птицеводства сдерживается рядом природно-экологических и экономических факторов. К их числу относятся: суровый климат с низкой среднегодовой и зимней температурой при резком колебании световой экспозиции, отсутствии собственной кормовой базы и сложности их доставки. 
Проблемы адаптации кур-несушек в условиях Крайнего Севера, особенно к стрессфакторам в промышленном птицеводстве, представляют большой теоретический и практический интерес.

В условиях Якутии нами установлено, что при поддержании оптимального температурновлажностного и светового режима резких колебаний фризиологических показателей у курнесушек не возникает. Продуктивность их была высокой. При этом состояние резистентности кур-несушек полностью зависело от основных физических показателей микроклимата, то есть от температурно-влажностного режима в птич- никах, в свою очередь зависимых от влияния экстремальных условий Севера, т. е. от сильного холода в зимний и жары - в летний периоды.

Среднее содержание аммиака во все периоды наблюдения в птичниках превышало ПДК на 3-5 мr/M.

Удаление отработанного воздуха в птичнике через вытяжную вентиляцию с выбросом отработанного воздуха на территорию в холодный период года отвечает гигиеническим требованиям по обеспечению необходимых условий для эфффективного удаления отработанного воздуха, меньше загрязняет воздушный бассейн территории птицефабрики.

Таблица 2

\section{Показатели микроклимата птичника до и после частичной реконструкции приточной вентиляции}

\begin{tabular}{|c|c|c|c|c|c|c|}
\hline \multirow{3}{*}{ Показатель } & \multicolumn{6}{|c|}{ Точка } \\
\hline & \multicolumn{2}{|c|}{1} & \multicolumn{2}{|c|}{2} & \multicolumn{2}{|c|}{3} \\
\hline & До & После & До & После & До & После \\
\hline $\mathrm{t},{ }^{\circ} \mathrm{C}$ & 14,2 & 18,5 & 16,8 & 18,0 & 15,3 & 17,6 \\
\hline $\mathrm{R}, \%$ & 75,0 & 65,5 & 70,0 & 65,0 & 60,0 & 64,0 \\
\hline 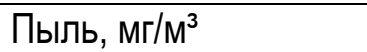 & $30,1 \pm 0,6$ & $28,0 \pm 0,4$ & $32,0 \pm 0,4$ & $30,0 \pm 0,3$ & $33,1 \pm 0,5$ & $30,5 \pm 0,4$ \\
\hline 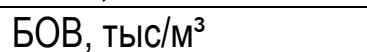 & $66,4 \pm 3,05$ & $65,0 \pm 0,9$ & $70,9 \pm 3,8$ & $66,9 \pm 1,2$ & $96,4 \pm 2,4$ & $88,3 \pm 1,6$ \\
\hline Концентрация $\mathrm{CO}_{2,} \%$ & $0,18 \pm 0,008$ & $0,18 \pm 0,004$ & $0,19 \pm 0,006$ & $0,18 \pm 0,005$ & $0,20 \pm 0,004$ & $0,19 \pm 0,002$ \\
\hline 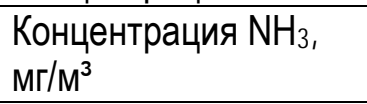 & $12,0 \pm 0,2$ & $11,0 \pm 0,3$ & $10,0 \pm 0,2$ & $9,0 \pm 0,15$ & $9,0 \pm 0,2$ & $8,0 \pm 0,15$ \\
\hline Сохранность, \% & 85,3 & 98,0 & 84,9 & 97,9 & 84,3 & 97,7 \\
\hline Достоверность (P) & $P \leq 0,05$ & $P \leq 0,05$ & $P \leq 0,05$ & $P \leq 0,05$ & $P \leq 0,05$ & $P \leq 0,05$ \\
\hline
\end{tabular}

В таблице 2 указаны точки измерения: 1 начало производственного зала; 2 - середина; 3 - конец зала. Температурно-влажностный режим после реконструкции стабилизировался. До реконструкции получены данные снижения температуры до нижнего критического состояния в начале зала $\left(14^{\circ} \mathrm{C}\right)$. Остальные показатели - в пределах гигиенической нормы, существенных различий не имеют.

\section{Выводы}

1. При понижении температуры наружного воздуха до минус $45^{\circ} \mathrm{C}$ и ниже температурновлажностный режим не отвечал ветеринарногигиеническим требованиям: температура была ниже, а влажность выше, влажный холодный воздух отрицательно действовал на организм птиц.
Однако после реконструкции вентиляционноотопительной системы в птичниках, когда подавался теплый подогретый воздух по периметру помещения, относительная влажность снизилась, воздух стал суше и температура в помещении повысилась, что послужило оптимизации параметров микроклимата.

2. В условиях Якутии нами установлено, что при поддержании оптимального температурновлажностного и светового режима резких колебаний фризиологических показателей у курнесушек не возникает.

3. В условиях Якутии при температуре наружного воздуха минус $50{ }^{\circ} \mathrm{C}$ и ниже немаловажное значение имеет организация утеплительных работ для ограждающих конструкций, эфффективная отопительная и вентиляционная система. 


\section{Литература}

1. Егорова В.С., Саввинова М.С. Санитарногигиеническая оценка воздушной среды птичников при их реконструкции и внедрении инновационных технологий в условиях Якутии // Аграрный вестник Урала. - 2011. № 10. - C. 18.

2. Волков Г.К., Дорофееев А.А. Контроль за проектированием и строительством животноводческих объектов // Ветеринария. 1971. - № 9. - С. 16.

3. Саввинова М.С. Гигиена содержания животных в природно-климатических условиях Якутии. - М.: Стерх, 2005. - 140 с.

4. Саввинова М.С., Егорова В.С. Применение современных приборов для мониторинга микроклимата производственной среды птичников в условиях Якутии. - URL: http://ofernio.ru/portal/modules/news.

5. Саввинова М.С., Егорова В.С. Производственные вредности в птичниках в условиях Якутии // Казанская наука. - 2011. - № 10. C. 357.

6. Фисинин В.И. Перспективы развития птицеводства // Экономика. - 2000. - № 5. C. 67.

\section{Literatura}

1. Egorova V.S., Savvinova M.S. Sanitarnogigienicheskaya ocenka vozdushnoj sredy ptichnikov pri in rekonstrukcii i vnedrenii innovacionnyh tekhnologij v usloviyah Yakutii /l Agrarnyj vestnik Urala. - 2011. - № 10. S. 18.

2. Volkov G.K., Dorofeev A.A. Kontrol' za proektirovaniem i stroitel'stvom zhivotnovodcheskih ob"ektov // Veterinariya. - 1971. № 9. - S. 16.

3. Savvinova M.S. Gigiena soderzhaniya zhivotnyh v prirodno-klimaticheskih usloviyah YAkutii. - M.: Sterh, 2005. - 140 s.

4. Savvinova M.S., Egorova V.S. Primenenie sovremennyh priborov dlya monitoringa mikroklimata proizvodstvennoj sredy ptichnikov $\mathrm{v}$ usloviyah YAkutii. - URL: http://ofernio.ru/portal/modules/news.

5. Savvinova M.S., Egorova V.S. Proizvodstvennye vrednosti $v$ ptichnikah $v$ usloviyah Yakutii /I Kazanskaya nauka. - 2011. № 10 - S. 357.

6. Fisinin V.I. Perspektivy razvitiya pticevodstva // Ekonomika. - 2000. - № 5. - S. 67. 